Pak. j. sci. ind. res. Ser. B: biol. sci. 2020 63B(1) 30-36

\title{
Impact of Hormones on the Proliferation of Shoots and Initiation of Roots in Salvia santolinifolia (Boiss), A High Value Medicinal Herb
}

\author{
Tour Jan ${ }^{a *}$, Beena Naqvi ${ }^{\mathrm{b}}$, Ali Hazrat ${ }^{\mathrm{a}}$, Raiha Qadric, Muhammad Nisar ${ }^{\mathrm{a}}$, \\ Nasrullah Khan ${ }^{\mathrm{a}}$, Muhammad Asif Nawaz ${ }^{\mathrm{d}}$ and Sidra Pervez \\ ${ }^{a}$ Department of Botany, University of Malakand, Dir Lower, Chakadara, KP, Pakistan \\ ${ }^{b}$ PCSIR Laboratories Complex Karachi, Karachi, Pakistan \\ ${ }^{\mathrm{c}}$ Department of Botany, University of Karachi, Karachi, Pakistan \\ ${ }^{\mathrm{d}}$ Department of Biotechnology, SBBU Sheringal, Dir Upper, Pakistan \\ e Department of Microbiology, Hazera University, Mansehra, KP, Pakistann
}

(received December 20, 2017; revised September 5, 2018; accepted September 7, 2018)

\begin{abstract}
Salvia santolinifolia is a medicinal plant and an efficient in vitro conservation system is established. The influence of $\mathrm{N}_{6}$ Benzylaminopurine (BAP), $\mathrm{N}_{6}$-(2-isopentyl)-adenine (2iP) and Kinetin at various concentrations were evaluated, single and in mixture with NAA (Naphthalene acetic acid) for the production of auxiliary shoots from nodal explants of $S$. santolinifolia. BAP at $3.0 \mathrm{mg} / \mathrm{L}$ in MS1 media produced maximum (11.66 \pm 3.38$)$ number of shoots while elongated $(5.37 \pm 1.45)$ shoots were produced in the $\mathrm{MS}_{2}$ medium in subcultures at $2.0 \mathrm{mg} / \mathrm{L}$ of $2 \mathrm{iP}$. Least number of shoots were formed when auxin and cytokinin were used in combination. Length of culture, age was an important consideration for the initiation and development of roots. Rooting of shoot was attained with Indol-3-butyric acid (IBA) $(3.0 \mathrm{mg} / \mathrm{L})$ from shoots of $4^{\text {th }}, 5^{\text {th }}$ and $6^{\text {th }}$ subculture while shoots taken from $1^{\text {st }}, 2^{\text {nd }}$ and $3^{\text {rd }}$ subculture failed to form roots.
\end{abstract}

Keywords: micropropagation, multiplication, nodal explants, Salvia santolinifolia

\section{Introduction}

Lamiaceae family is miscellaneous comprising of about 180 genera and more than 3500 species. Numerous species of Lamiaceae are used in the remedy of guinea worm, itch, and cough are useful to injuries as bandage Kirtikar and Basu (1935). The medicinal worth of Lamiaceae seems to be due to alkaloids. Antioxidant rosmarinic acid was obtained in considerable amount in Salvia officinalis Kintzios et al. (1999). Family Lamiaceae is prominent for its ingredients with an antitumor action (Ginda and Kakisawa, 1990). A variety of chemical constituents have been isolated from these species which show antifondant and anti-fungal properties (Esquivel et al., 1985). A remarkably valuable compounds followed numerous chemical groups like as essential oils, terpenoid and phenolic derivatives have been isolated from the genus Salvia which object conspicuously in the pharmacopoeias of several countries in the world (Ulubelen and Topou, 1992; Banthrop, 1989).

Considerable development has been made in the area of in vitro manufacture of several compounds, like rosmarinic acid and cryptotanshinon. The use of

*Author for correspondence; E-mail: tour_jan@yahoo.com biotechnological approaches for the proliferation of these species is somewhat restricted. There is a cumulative importance in the improvement of effective procedures for the micro-propagation of certain Salvia species, in order to form a comparatively fast system for generating disease free and true-to-type cloned plant from outstanding genotypes. In addition, there is considerable suggestion that plant natural products manufacture can be improved by the in vitro initiation of morphogenesis, so that the in vitro produced plants can be a suitable source of pharmacologically energetic compounds. The techniques of plant tissue culture would be vital for the safety of endangered or rare species. Some Salvia species have been micropropagated (Gostin, 2008; Arikat et al., 2004; Morimoto et al., 1994). A report is available on the micropropagation of this species (Jan and Khatoon, 2014) but there is no detail information on the in vitro induction of roots of Salvia santolinifolia. The present work reported for the effect of plant growth regulators for the multiplication of shoots and induction of roots of Salvia santolinifolia.

\section{Materials and Methods}

Salvia santolinifolia was collected from Karachi University site and identified in Herbarium, Department 
of Botany, University of Karachi. Voucher specimen accession (\#67845) was placed in the Herbarium. Branches (7-10 cm long) were removed from 1-2 years old, fully mature plant of Salvia santolinifolia, growing in natural habitat. Excised shoots were washed with tap water for 8-12 mins and then sterilized with $0.05 \%$ Mercuric chloride solution including few drops of Tween-20 for 10-12 mins. Disinfected shoots were rinsed 3 times with sterile distilled water before inoculation. Plant growth regulators were supplemented before sterilizing the medium. After an accumulation of all ingredients of medium, $\mathrm{pH}$ was adjusted to 5.55.55 and agar (agar-agar Mikrobiologic, Merck, USA) $0.6 \%$ was used as solidifying agent.

Murashige and Skoog (1962) medium was used in this investigation. Explants of the desired size were inoculated on the following media for the initiation and development of shoots:

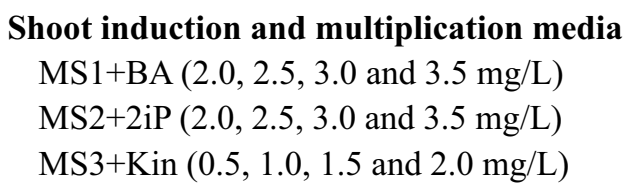

\section{Root induction media}

MS4+IBA (2.0, 2.5, 3.0 and $3.5 \mathrm{mg} / \mathrm{L})$

Data were collected after 21-35 days of culture initiation. All cultures were maintained at $26 \pm 2{ }^{\circ} \mathrm{C}$ under a light system of $16 \mathrm{~h}$ days and $8 \mathrm{~h}$ nights. In the growth section light was provided from cool white fluorescent tubes.

\section{Results and Discussion}

Formation of axillary shoots. Nodal explants on cytokinins containing media produced axillary shoots (Table 1) nevertheless, media comprising auxins stopped shoots formation, as these hormones helps callus induction (Table 2). Likewise, medium lacking hormones, shows that neither initiation of axillary shoots nor the generation of callus occurred (Table 1). At various levels of BAP, $3.0 \mathrm{mg} / \mathrm{L}$ formed maximum numbers of shoots (Table 1). High $(3.5 \mathrm{mg} / \mathrm{L})$ and low concentrations of BAP $(2.0 \mathrm{mg} / \mathrm{L})$ formed less numbers of shoots per explants (Table 1). With 2iP, maximum numbers $(2.26 \pm 107)$ of shoots were obtained at $3.5 \mathrm{mg} / \mathrm{L}$ and length $(4.26 \pm 24 \mathrm{~cm})$ at $3.0 \mathrm{mg} / \mathrm{L}$. The shoots formed in the presence of Kinetin were fewer in number and short in length (Table 1). However, complete inhibition of shoots was observed at $0.5 \mathrm{mg} / \mathrm{L}$ of Kinetin (Table 1). The formation of callus occurred occasionally on BAP and 2iP containing media. If it formed, they were very little and arise from the basal portion of explant (Table 1).

Table 1. The influence of hormones on nodal explants for shoots initiation and development

\begin{tabular}{lllll}
\hline \hline Media & $\begin{array}{l}\text { Hormones } \\
(\mathrm{mg} / \mathrm{L})\end{array}$ & $\begin{array}{l}\text { Numbers of } \\
\text { shoots } \pm \mathrm{SE}\end{array}$ & $\begin{array}{l}\text { Length of } \\
\text { shoots } \\
(\mathrm{cm}) \pm \mathrm{SE}\end{array}$ & Callus \\
\hline $\mathrm{MS}_{1}$ & BAP & & & \\
& 2.0 & $2.26 \pm 1.07$ & $3.61 \pm 2.54$ & \pm \\
& 2.5 & $2.35 \pm 1.5$ & $3.61 \pm 1.35$ & \pm \\
& 3.0 & $2.4 \pm 0.95$ & $4.13 \pm 2.82$ & \pm \\
& 3.5 & $2.2 \pm 1.47$ & $4.11 \pm 2.23$ & \pm \\
$\mathrm{MS}_{2}$ & $2 \mathrm{PP}$ & & & \\
& 2.0 & $2.25 \pm 0.87$ & $3.47 \pm 2.94$ & \pm \\
& 2.5 & $2.20 \pm 0.85$ & $4.06 \pm 2.34$ & \pm \\
& 3.0 & $2.23 \pm 1.45$ & $4.26 \pm 3.02$ & \pm \\
& 3.5 & $2.26 \pm 1.48$ & $3.94 \pm 2.31$ & \pm \\
$\mathrm{MS}_{3}$ & Kinetin & & & \\
& 0.5 & 0.0 & 0.0 & 0.0 \\
& 1.0 & $1.6 \pm 1.03$ & $3.75 \pm 1.87$ & 0.0 \\
& 1.5 & $1.4 \pm 0.89$ & $2.25 \pm 1.43$ & 0.0 \\
& 2.0 & $1.2 \pm 1.53$ & $2.48 \pm 0.99$ & 0.0 \\
Control & 0.0 & 0.0 & 0.0 & 0.0 \\
\hline \hline Symbol: SE & & & & \\
\hline
\end{tabular}

Symbol: $\mathrm{SE}=$ standard error; $\pm=$ occasionally formed callus.

Table 2. Shoots formation under the influence of auxin/cytokinins from nodal segments of Salvia santolinifolia

\begin{tabular}{llll}
\hline \hline $\begin{array}{l}\text { Hormones } \\
(\mathrm{mg} / \mathrm{L})\end{array}$ & (\%) Response & $\begin{array}{l}\text { Mean no. } \\
\text { of shoots }\end{array}$ & $\begin{array}{l}\text { Extent of } \\
\text { callus formation }\end{array}$ \\
\hline $\mathrm{NAA} / \mathrm{BA}$ & & & \\
$1.0 / 0.5$ & 28.57 & 0.0 & ++ \\
$1.0 / 1.0$ & 28.57 & 0.0 & + \\
$1.0 / 2.0$ & 42.85 & $3.74 \pm 38$ & -- \\
$\mathrm{NAA} / 2 \mathrm{iP}$ & & & \\
$1.0 / 0.5$ & 57.14 & 0.0 & ++ \\
$1.0 / 1.0$ & 57.14 & 0.0 & ++ \\
$1.0 / 2.0$ & 28.57 & $3.21 \pm 56$ & -- \\
$\mathrm{NAA} / \mathrm{Kin}$ & & & \\
$1.0 / 0.5$ & 42.85 & 0.0 & ++ \\
$1.0 / 1.0$ & 42.85 & 0.0 & +++ \\
$1.0 / 2.0$ & 42.85 & $2.63 \pm 71$ & -- \\
NAA & & & \\
1.0 & 42.85 & 0.0 & ++++ \\
\hline \hline
\end{tabular}

$(+)=$ visible callus growth; $(++)=$ small callus growth; $(+++)$ $=$ good callus growth; $(++++)=$ excellent callus growth; $(--)=$ no callus. 
Shoots multiplication during first subculture. To enhance shoots multiplication the regenerated shoots of $\mathrm{MS}_{1}$ and $\mathrm{MS}_{2}$ media (Table 1) were subcultured on same media $\left(\mathrm{MS}_{1}\right.$ and $\left.\mathrm{MS}_{2}\right)$ keeping the hormones concentration the same (Table 3). During subculturing the formation of shoots started after 3-4 day of inoculation. In subculture maximum number $(11.66 \pm 3.38)$ and length $(3.83 \pm 1.23 \mathrm{~cm})$ of shoots were formed at intermediate level $(3.0 \mathrm{mg} / \mathrm{L})$ of $\mathrm{BA}$ in $\mathrm{MS}_{1}$ media (Table 3) (Fig. 1a). The development of shoots at lower and higher concentrations of $\mathrm{BA}$ in $\mathrm{MS}_{1}$ were reduced (Table 3). The incorporation of $2 \mathrm{iP}$ in $\mathrm{MS}_{2}$ media encouraged shoots development at all concentrations (Table 2). At $2.0 \mathrm{mg} / \mathrm{L}$ of $2 \mathrm{iP} 9.40 \pm 2.04$ shoots per explants and $5.37 \mathrm{~cm}$ length of shoots were formed (Fig. 1). Whereas at $3.0 \mathrm{mg} / \mathrm{L}$ of $2 \mathrm{iP}$ fewer numbers of shoots were formed (Table 3 ).

The influence of Auxin/Cytokinins ratio on shoot multiplication. Auxin (NAA) at $1.0 \mathrm{mg} / \mathrm{L}$ with lower concentrations of cytokinis (BAP, 2iP \& Kinetin) in the media absolutely blocked the development of shoots and improved callus growth Table 2. The callus formed was yellowish white and soft in appearance (Table 2). Auxin (NAA $1.0 \mathrm{mg} / \mathrm{L}$ ) with high cytokinins (BA, 2iP \& $\mathrm{Kin} 2.0 \mathrm{mg} / \mathrm{L}$ ) favored shoots formation and inhibited callus development (Table 3 ). The shoots formed were few in numbers and thinner in appearance. However, maximum callus formation occurred in medium containing single auxin (NAA $1.0 \mathrm{mg} / \mathrm{L}$ ). Morphology of the induced callus were similar to the calli made on media having combination of auxin and cytokinins.

Table 3. The effect of various concentration of BAP, 2iP and Kinetin in subculture

\begin{tabular}{lllll}
\hline \hline Media & $\begin{array}{l}\text { Hormones } \\
(\mathrm{mg} / \mathrm{L})\end{array}$ & $\begin{array}{l}\text { Numbers of } \\
\text { shoots } \pm \mathrm{SE}\end{array}$ & $\begin{array}{l}\text { Length of } \\
\text { shoots } \\
(\mathrm{cm}) \pm \mathrm{SE}\end{array}$ & Callus \\
\hline $\mathrm{MS}_{1}$ & $\mathrm{BAP}$ & & & \\
& 2.0 & $9.83 \pm 3.62$ & $3.8 \pm 0.51$ & \pm \\
& 2.5 & $11.50 \pm 5.47$ & $3.42 \pm 1.38$ & \pm \\
& 3.0 & $11.66 \pm 3.38$ & $3.83 \pm 1.23$ & \pm \\
& 3.5 & $10.50 \pm 4.74$ & $3.35 \pm 1.65$ & \pm \\
$\mathrm{MS}_{2}$ & $2 \mathrm{PP}$ & & & \\
& 1.5 & $7.60 \pm 4.75$ & $4.97 \pm 1.54$ & \pm \\
& 2.0 & $9.4 \pm 3.59$ & $5.37 \pm 1.45$ & \pm \\
& 2.5 & $8.5 \pm 3.23$ & $4.34 \pm 2.33$ & \pm \\
& 3.0 & $5.83 \pm 3.04$ & $3.43 \pm 1.42$ & \pm \\
Control & - & - & - & - \\
\hline
\end{tabular}

$\overline{\text { Symbol: } \mathrm{SE}=\text { standard error; } \pm=\text { occasionally formed callus. }}$.
The effect of gibberellic acid (GAç) and activated charcoal in combination with BA. The addition of $\mathrm{GA}_{3}$ in the medium were inhibitory at both low and high levels. The incorporation of low level $(0.2 \mathrm{mg} / \mathrm{L})$ of $\mathrm{GA}_{3}$ to the BAP $(3.0 \mathrm{mg} / \mathrm{L})$ supplemented media reduced shoots multiplication. The regenerated shoots produced narrow leaves with elongated petioles with BAP. In the presence of high concentration of $\mathrm{GA}_{3}$ $(1.0 \mathrm{mg} / \mathrm{L})$ the effect was more pronounced and the multiplication of shoots were further reduced (Table 4). On other hand elongation of shoots was less
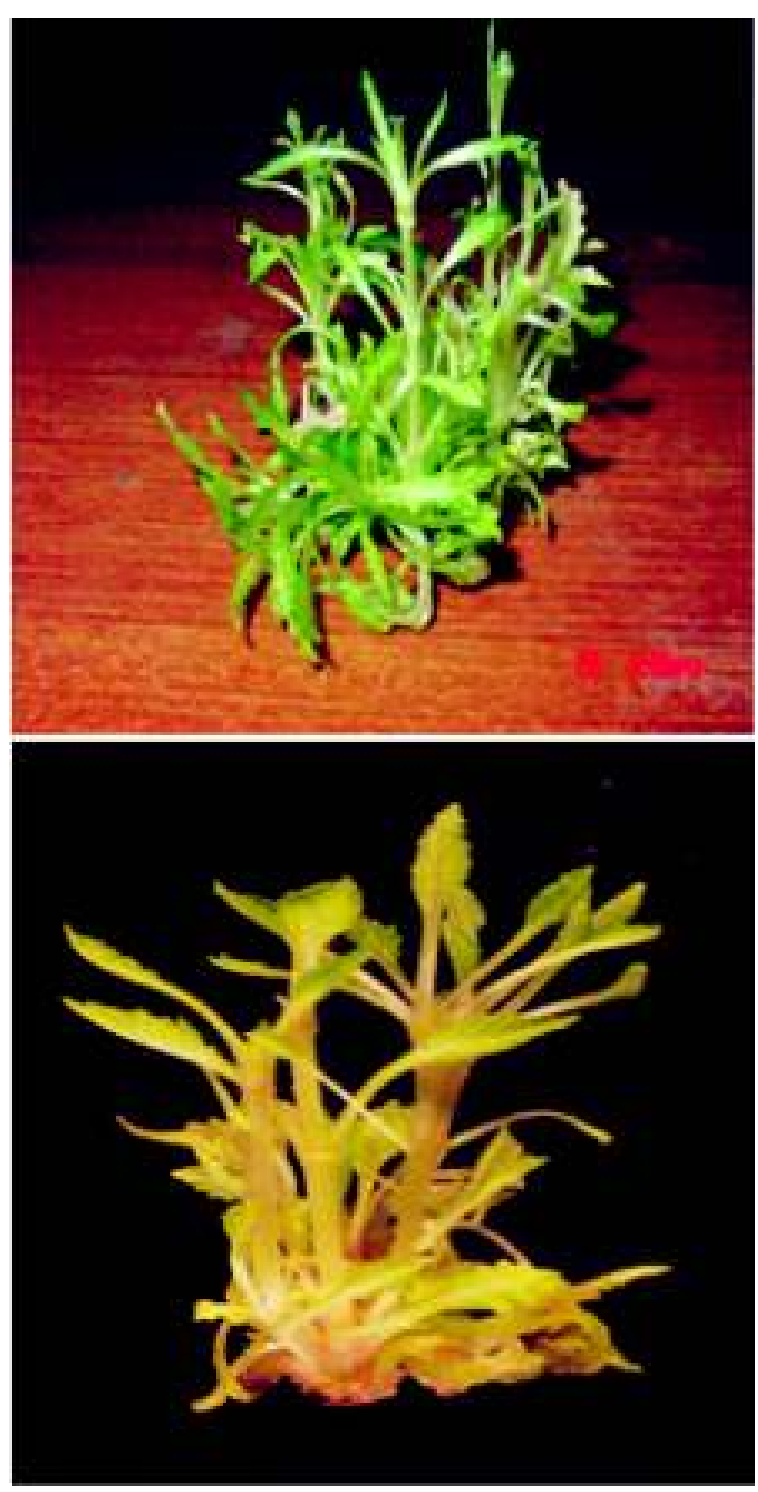

Fig. 1. Shoot multiplication in subculture. Shoots formed on (a) $\mathrm{MS}_{1}+\mathrm{BAP}(3.0 \mathrm{mg} / \mathrm{L})$ (b) $\mathrm{MS}_{2}+2 \mathrm{iP}(2.0 \mathrm{mg} / \mathrm{L})$. 
affected by the presence of $0.2 \& 1.0 \mathrm{mg} / \mathrm{L} \mathrm{GA}_{3}$ when mixed with $3.0 \mathrm{mg} / \mathrm{L}$ of BA in the medium (Table 4) Callus formed in the presence of both levels of $\mathrm{GA}_{3}$ $(0.2$ and $1.0 \mathrm{mg} / \mathrm{L})$ but its quantity was very small.

The addition of activated charcoal $(0.3 \%)$ to the shoots multiplication medium (BAP $3.0 \mathrm{mg} / \mathrm{L}$ ) during subculture completely inhibited multiplication and elongation of axillary shoots (Table 4). The growth of the inoculated explants was also stopped. After remaining for 15-20

Table 4. The influence of gibberellic acid and activated charcoal in BA containing shoot multiplication medium after 25 days

\begin{tabular}{cllll}
\hline $\begin{array}{l}\text { Hormones } \\
(\mathrm{mg} / \mathrm{L})\end{array}$ & $\begin{array}{l}(\%) \\
\text { Response }\end{array}$ & $\begin{array}{l}\text { Number of } \\
\text { shoots } \pm \mathrm{SD} \\
(\mathrm{cm}) \pm \mathrm{SD}\end{array}$ & $\begin{array}{l}\text { Length of } \\
\text { shoots }\end{array}$ & Callus \\
\hline $\mathrm{BA}+\mathrm{GA} 3$ & & & & \\
$3.0+0.2$ & 88.88 & $7.28 \pm 1.97$ & $3.44 \pm 1.15$ & \pm \\
$3.0+1.0$ & 71.14 & $4.66 \pm 3.18$ & $2.83 \pm 1.71$ & \pm \\
$\mathrm{BA}+\mathrm{AC}$ & & & & \\
$3.0+0.3 \%$ & 100 & 0.0 & 0.0 & 0.0 \\
$\mathrm{BAP}$ & & & & \\
3.0 & 87.5 & $12.14 \pm 5.47$ & $3.79 \pm 0.51$ & \pm \\
\hline \hline
\end{tabular}

$( \pm)=$ occasionally formed callus.

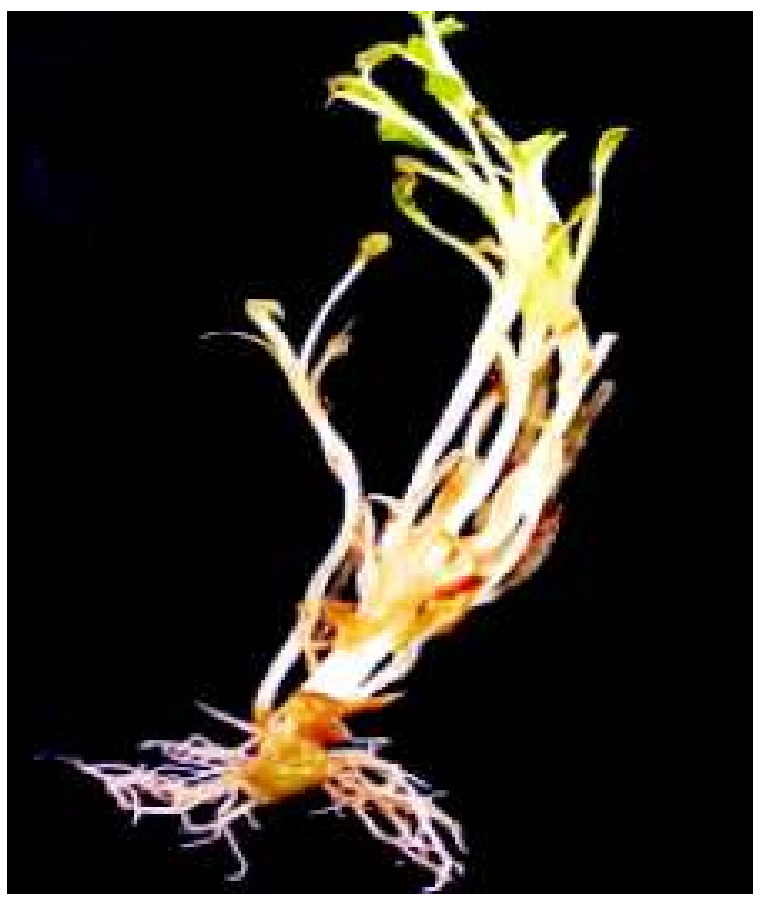

Fig. 2. Shoots rooting with $\mathrm{IBA}(3.0 \mathrm{mg} / \mathrm{L})$, taken from $5^{\text {th }}$ subculture after 30 days of culture. days on the activated charcoal supplemented medium, stem and leaves of the inoculated shoots gradually turned light green and then turned white and finally became dead. The callus formation was also stopped on medium containing activated charcoal (Table 4).

Root regeneration. For root regeneration, shoots of $1^{\text {st }}$ to $6^{\text {th }}$ subcultures were utilized. Results of our experiments illustrated that the onset and length of roots produced from $4^{\text {th }}, 5^{\text {th }}$ and $6^{\text {th }}$ subcultures were not under the impact of various concentrations of IBA. Duration of cultured shoots on cytokinins supplemented media and the type of hormones affected the development of roots from regenerated shoots. The shoots isolated from $1^{\text {st }}$, $2^{\text {nd }}$ and $3^{\text {rd }}$ subcultures were failed to formed roots on media added with IBA, NAA and IBA (Table 5). On these media the shoots became browned and died after 14-16 days of inoculation. However, when shoots were taken from $4^{\text {th }}$ subculture and transferred to rooting media having various concentrations of IBA, NAA and IAA, some shoots formed roots with IBA (Table 5). The roots appeared after 12 to 15 days of culture. Among various concentrations, $2.5 \mathrm{mg} / \mathrm{L}$ of IBA formed a good number of roots per shoots $(3.5 \pm 0.5)$. The percent response of rooting from the shoots of $4^{\text {th }}$ subcultures was low (7.14 to $23.07 \%$ ) (Table 5). Whereas IAA and NAA failed to form roots in the shoots taken from $4^{\text {th }}$ subculture (Table 5). Good numbers and percentage response of shoots rooting were produced in shoots taken from $5^{\text {th }}$ subculture with IBA (Table 5). IBA at the level of $3.0 \mathrm{mg} / \mathrm{L}$ produced $7.6 \pm 3.1$ roots per shoots and the length of roots were $4.18 \pm 1.56 \mathrm{~cm}$ (Table 5). The shoots taken from $6^{\text {th }}$ subcultures for rooting, the percentage of shoots rooting, increased to $79.09 \%$, whereas the formation of roots decreased (4.2 \pm 2.36$)$ with IBA at $3.0 \mathrm{mg} / \mathrm{L}$ (Table 5).

In the initial experiments, the influence of diverse concentration of BA, 2iP and Kinetin was confirmed for the initiation of shoots from the nodal parts of Salvia santolinifolia. Shoots formation started after 4-6 days of inoculation. Among the three types of cytokinin, BAP produced maximum shoots formation followed by $2 \mathrm{iP}$ and Kinetin in primary culture and as well as in the subculture (Table 1-3). The influence of BAP on the initiation and development of shoots in other Salvia species has been reported by several authors. In Salvia hispanica higher proliferation of shoots was acquired with BA (Bueno et al., 2010). With BAP and NAA maximum multiplication rate of shoots were obtained in Salvia guaranitica (Echeverrigaray et al., 2010). 
Table 5. The influence of different types of auxin on the induction of roots from shoots regenerated in vitro

\begin{tabular}{|c|c|c|c|}
\hline \multirow[t]{2}{*}{ Hormones } & \multirow[t]{2}{*}{ Rooting (\%) } & \multicolumn{2}{|c|}{ Numbers and length of roots produced in shoots taken from $4^{\text {th }}$ subculture } \\
\hline & & Mean number of roots & Mean length of roots \\
\hline \multicolumn{4}{|l|}{ IBA } \\
\hline 2.0 & 7.14 & $1.0 \pm 0.41$ & $<0.5$ \\
\hline 2.5 & 23.07 & $3.5 \pm 0.5$ & $<0.5$ \\
\hline 3.0 & 7.17 & $1.0 \pm 0.23$ & $<0.5$ \\
\hline 3.5 & 14.8 & $1.0 \pm 0.54$ & $<0.5$ \\
\hline \multicolumn{4}{|l|}{ NAA } \\
\hline 1.5 & - & - & - \\
\hline 2.0 & - & - & - \\
\hline 2.5 & - & - & - \\
\hline \multicolumn{4}{|l|}{ IAA } \\
\hline 2.0 & - & - & - \\
\hline 2.5 & - & - & - \\
\hline \multirow[t]{3}{*}{3.0} & - & - & - \\
\hline & & \multicolumn{2}{|c|}{ Numbers and length of roots induced from shoots of $5^{\text {th }}$ subculture } \\
\hline & & Mean numbers of roots & Mean length of roots \\
\hline \multicolumn{4}{|l|}{ IBA } \\
\hline 2.0 & 62.5 & $3.2 \pm 1.7$ & $3.87 \pm 0.8$ \\
\hline 2.5 & 62.5 & $6.4 \pm 2.35$ & $3.74 \pm 2.23$ \\
\hline 3.0 & 71.14 & $7.6 \pm 4.31$ & $4.18 \pm 1.56$ \\
\hline 3.5 & 50.0 & $4.5 \pm 2.08$ & $3.91 \pm 0.8$ \\
\hline \multicolumn{4}{|l|}{ NAA } \\
\hline 1.5 & - & - & - \\
\hline 2.0 & - & - & - \\
\hline 2.5 & - & - & - \\
\hline \multicolumn{4}{|l|}{ IAA } \\
\hline 2.0 & - & - & - \\
\hline 2.5 & - & - & - \\
\hline \multirow[t]{3}{*}{3.0} & - & - & - \\
\hline & & \multicolumn{2}{|c|}{ Numbers and length of roots induced from shoots of 6 th subculture } \\
\hline & & Mean number of roots & Mean length of roots \\
\hline \multicolumn{4}{|l|}{ IBA } \\
\hline 2.0 & 68.73 & $3.36 \pm 0.96$ & $3.87 \pm 2.64$ \\
\hline 2.5 & 57.89 & $3.17 \pm 2.64$ & $4.11 \pm 1.99$ \\
\hline 3.0 & 79.09 & $4.2 \pm 2.36$ & $3.27 \pm 1.42$ \\
\hline 3.5 & 76.57 & $3.78 \pm 2.12$ & $3.25 \pm 1.76$ \\
\hline \multicolumn{4}{|l|}{ NAA } \\
\hline 1.5 & - & - & - \\
\hline 2.0 & - & - & - \\
\hline 2.5 & - & - & - \\
\hline \multicolumn{4}{|l|}{ IAA } \\
\hline 2.0 & - & - & - \\
\hline 2.5 & - & - & - \\
\hline 3.0 & - & - & - \\
\hline
\end{tabular}

Shoots less than $0.5 \mathrm{~cm}$ were neglected.

From nodal explants of Salvia fruticosa large number of shoots were obtained on media containing BAP (Arikat, 2004). Salvia chamelaegnea also produced shoots on medium containing BA (Huang and Staden, 2002). From stem and petioles of Salvia canariensis direct shoots induction has been reported with PAP and
NAA (Mederos-Molina, 2004). Similar results have also been reported in species other than Salvia. Maximum number of shoots has been obtained with BAP rom shoot tip of Basilicum polstachyon (Amutha et al., 2008). The nodal explants of Gynura procumbens formed more numbers of shoots with BAP (Keng et al., 
2009). In our study the shoots formed in Salvia santolinifolia was not disappointing, but the key influence of 2iP was elongation of shoots. In Salvia blancoana elongated shoots were obtained on media supplemented with 2iP (Cuenca and Amo-Maro, 2000).

In this research the main effect of Kinetin was meagre about the induction, proliferation and elongation of shoots. All the shoots formed in the presence of Kinetin were few in number and short in length, however, there are sufficient reports in the literature on the encouraging results of Kinetin on the stimulation and proliferation of shoots of several species. Admirable shoot propagation was achieved with Kinetin from nodal segments of Salvia valentine (Cuenca and Amo-Maro, 2000). Length of culture period is a vital concern in tissue culture and depends upon the time essential for the accomplishment of many stages of growth of culture. In our study with Salvia santolinifolia a culture age of more than 120 days was essential to regenerate shoots for the development of roots. Our research finding shows that roots formation is not possible in the in vitro shoots if the shoots were not sustained for a passé of 4 months (subculture) on BAP comprising media. In several treatments with IBA, the in vitro regenerated shoots of Salvia santolinifolia formed roots. The rooting of in vitro shoots by the use of IBA has previously been described for several plant species, such as Salvia officinalis (Kacar et al., 2009), Salvia blancoana and Salvia valentine (Cuenca and Amo-Maro, 2000). The in vitro produced shoots of Salvia fruticosa formed the highest rooting percentage with IBA compared to those cultured with IAA or NAA. Banthrop et al. (1989). Salvia brachyodon formed roots on medium containing with IAA, IBA and NAA (Misic et al., 2006). Good roots regeneration occurred in Salvia chamelaeagnea on MS medium supplemted $0.5 \mathrm{mg} / \mathrm{L}$ of NAA (Huang and Staden, 2002). Shoots of Salvia officinalis were well rooted on medium containing Kinetin $(0.1 \mathrm{mg} / \mathrm{L})$ and IAA $(5.0 \mathrm{mg} / \mathrm{L})$ as described by Olszowska and Furmanowa (1990).

\section{Conclusion}

This is the first detailed report of the impact of hormones on the in vitro mass multiplication of Salvia santolinifolia through nodal cutting. $\mathrm{N}_{6}$-Benzyl aminopurine (BAP) was confirmed as induction and multiplication hormone and $\mathrm{N}_{6}$-(2-isopentyl)-adenine (2iP) as shoots elongation hormone. Indole-3-butyric acid (IBA) was standardized as a sole hormone for the induction of roots.
Conflict of Interest. The authors declare no conflict of interest.

\section{References}

Amutha, A., Jawahar, M., Paul, J.R. 2008. Plant regeneration and in vitro flowering from shoot tip of Basilicumpolystachyon (L) Moench an important medicinal plant. Journal of Agriculture Technology, 4: 117-123.

Arikat A., Jawad, F.M., Karam, N.S., Shibli, R.A. 2004. Miropropagation and accumulation of essential oil in wild sage (Salvia fruticosa Mill.). Scientia Horticulturae, 100: 193-202.

Banthrop, D.V., Bilard, H.J., Brown, G.D. 1989. Enol esters of caffeic acid in several genera of the Lamiaceae. Phytochemistry, 28: 2109-2113.

Bueno, M., Sapio, O.D., Barolo, M., Villalonga, M.E., Busilacchi, H., Severin, C. 2010. In vitro response of different Salvia hispanica L. (Lamiaceae) explants. Molecular Medicinal Chemistry, 21: 125-126.

Cuenca, S., Amo-Maro, J.B. 2000. In vitro propagation of two Spanish endemic species of Salvia through bud proliferation. In Vitro Cellular Development Biology Plant, 36: 225-229.

Echeverrigaray, S., Carrer, R.P., Andrade, L.B. 2010. Micropropagation of Salvia guaranitica Benth. through axillary shoot proliferation. Brazilian Archives of Biology and Technology, 53: 883-888.

Esquivel, B., Mende, A., Ortega, A., Soriano-Garcia, M., Toscano, A., Rodriguez-Hahn, L. 1985. Neoclerodane type diterpenoids from Salvia Keerlii. Phytochemica, 24: 1769-1772.

Ginda, H., Kakisawa, H. 1990. Miltipolone, a new diterpenoidtropolone possessing cytotoxic activities from Salvia miltiorrhiza Bunge. Chemistery Letter, 19: 1599-1602.

Gostin, I. 2008. Effect of different plant hormones on Salvia officinalis cultivated in vitro. International Journal of Botany, 4: 430-436.

Huang, L.D., Staden, V. J. 2002. Salvia chamelaeagnea can be micropropagated and its callus induced to produce rosmarinic acid. South African Journal of Botany, 68: 177-180.

Jan, T., Khatoon, K. 2014. In vitro regeneration of Salvia santolinifolia. Pakistan Journal of Botany, 46: 325-328.

Kacar, O., Azkan, N., Coplii, N. 2009. Effect of different rooting media and indol butyric acid on rooting of 
stem cuttings in Sage (Salvia officinalis L. and Salvia triloba L.). Journal of Food Agriculture and Environment, 7: 349-352.

Keng, C.L., Yee, L.S., Pin, P.L. 2009. Micropropagation of Gynura procumbens (Lour.) Merr; an important medicinal plant. Journal of Medicinal Plant Research, 3: 105-111.

Kintzios, S., Nikolaou, A., Skoula, M. 1999. Somatic embryogenesis and in vitro rosmarinic acid accumulation in Salvia officinalis and Salvia fruticosa leaf callus cultures. Plant Cell Report, 18: 462466.

Kirtikar, K.R., Basu, B.D. 1935. Indian Medicinal Plants. Vol. 3, 852 pp., Lalit Mohan Basu Publisher, Allahabad, India.

Mederos-Molina, S. 2004. In vitro callus induction and plant from stem and petiole explants of Salvia canariensis L. Plant. Tissue Culture, 14: 167-172. Misic, D., Grubisic, D., Konjevic, R. 2006. Micropropagtion of Salvia branchodon through nodal explants. Biologia Plantarum, 50: 473-476.

Morimoto, S., Goto, Y., Shoyama, Y. 1994. Production of lithospermic acid and rosmarinic acid in callus tissue and regeneration plantlets of Salvia miltiorrhiza. Journal of Natural Product, 5: 817-823.

Murashige, T., Skoog, F. 1962. A revised medium for rapid growth and bioassays with tobacco tissue cultures. Plant Physiology, 15: 473-497.

Olszowska, O., Furmanowa, M. 1990. Micropropagation of Salvia officinalis by shoot buds. Planta Medica, 56: 637.

Ulubelen, A., Topcu, G. 1992. Abietane diterpenoids from Salvia pomifera. Phytochemistry, 31: 39493951. 